\title{
ADAPTASI DAN INOVASI TEKNOLOGI PERAHU NELAYAN DAN ALAT TANGKAP TRADISIONAL DI TELUK TOMINI
}

\author{
Technological adaptation and innovation in traditional fishing boat and fishing gear in Tomini \\ Gulf \\ Oleh:
}

Aziz Salam ${ }^{1 *}$, Zhulmaydin Chairil Fachrussyah $^{2}$

11Program Studi S2 Ilmu Kelautan dan Perikanan, Pascasarjana, Universitas Negeri Gorontalo, Kota Gorontalo, aziz_salam@ung.ac.id

2Fakultas Perikanan dan Ilmu Kelautan, Universitas Negeri Gorontalo, Kota Gorontalo, fachrussyah@ung.ac.id

* Korespondensi: aziz_salam@ung.ac.id

Diterima: 18 Oktober 2020; Disetujui: 22 September 2021

\begin{abstract}
The development of technology on traditional boats and fishing gear commonly used by fishing communities in Indonesia appears to be in slow pace while adaptation and technological innovation play a significant role in it. This study aims to analyze the adaptations and technological innovations applied in fishing communities for the development of capture fisheries technology in Tomini Gulf. Observations were made on fishing boats and totabito fishing gear. Data were obtained by measurement, sketch making, photographing, and in-depth interviews with boat craftsmen, fishermen and community leaders. Data were analyzed descriptively to produce drawings and descriptions of boats and fishing gear construction and to recognize adaptations and innovations. Adaptation and technological innovations occured partially in boats and the fishing gear leads to the development of traditional capture fisheries technology. Improvement of hull types and the use of fiberglass and PVC (polyvinyl chloride) materials as substitution to natural raw materials of wood, bamboo and rattan are seen as technological adaptations while innovation is found in the use of a waterproof LED (light-emitting diode) sircuit in a used syringe/ spoit plastic tube as a submerged light fishing aid the totabito squid fishing gear.
\end{abstract}

Keywords: adaptation, innovation, technology, fishing boat, fishing gear, traditional.

\section{ABSTRAK}

Pengembangan teknologi perahu dan alat tangkap tradisional yang digunakan oleh masyarakat nelayan di Indonesia tampaknya berjalan lambat, sementara adaptasi dan inovasi teknologi berperan dalam pengembangan teknologi tersebut. Penelitian ini bertujuan untuk menganalisis adaptasi dan inovasi teknologi apa saja yang berlaku dalam masyarakat nelayan untuk pengembangan teknologi perikanan tangkap di Teluk Tomini. Pengamatan dilakukan terhadap perahu nelayan dan alat tangkap totabito. Data diperoleh dengan pengukuran, pembuatan sketsa, pemotretan dan wawancara mendalam dengan pengrajin perahu, nelayan dan tokoh masyarakat. Data dianalisis secara deskriptif untuk membuat gambar perahu dan konstruksi alat tangkap dan untuk menemu-kenali adaptasi dan inovasi. Adaptasi dan inovasi teknologi yang terjadi secara parsial pada perahu nelayan dan alat tangkap mengarah kepada pengembangan teknologi perikanan tangkap tradisional. Bentuk-bentuk adaptasi teknologi yang teramati adalah penggunaan jenis lambung secara lebih baik serta penggunaan bahan fiberglass dan pipa PVC (polivinil klorida) sebagai pengganti bahan baku alami kayu, bamboo dan rotan. Inovasi teknologi pada alat tangkap 
cumi totabito adalah penggunaan lampu suntik LED (light-emitting diode) sebagai alat bantu light fishing.

Kata kunci: adaptasi, inovasi, teknologi, perahu nelayan, alat tangkap, tradisional.

\section{PENDAHULUAN}

Perikanan tangkap tradisional adalah usaha perikanan yang dijalankan oleh masyarakat nelayan dengan menggunakan alat dan sarana penangkapan berteknologi sederhana yang telah mereka kenal secara turuntemurun. Usaha perikanan tangkap tradisional berskala rumah tangga atau melibatkan kerabat dan tetangga dengan modal usaha yang relatif kecil. Boleh dikatakan bahwa usaha perikanan tangkap tradisional telah ada sejak awal masyarakat nelayan muncul di nusantara dan tetap menjadi kegiatan utama masyarakat pesisir sampai sekarang. Usaha perikanan laut di Indonesia dijalankan oleh 965.756 rumah tangga perikanan (BPS, 2019).

Menurut Salam (2017) perikanan tangkap tradisional dapat bertahan karena beberapa alasan, antara lain penguasaan teknologi sederhana dalam pembuatan alat tangkap dan sarana penangkapan (perahu dan alat bantu), kecenderungan nelayan untuk mempertahankan teknik yang dikuasai secara tradisi, serta terbatasnya akses langsung terhadap teknologi yang lebih baru. Di sisi lain, keterbatasan bahan baku alami, pengenalan teknologi baru oleh pemerintah atau nelayan dari daerah lain, serta kebutuhan ekonomi mendorong perikanan tradisional untuk terus beradaptasi terhadap keadaan dan berinovasi secara teknologi demi menjaga keberlangsungan usahanya.

Satria (2002) melihat bahwa perubahan teknologi perikanan secara antropologis sebagai suatu perubahan kebudayaan secara lambat-laun, salah satunya adalah terjadi melalui inovasi. Menurutnya, penemuan baru berupa alat dalam masyarakat disebut discovery, jika penemuan itu diakui dan diterima masyarakat, maka akan disebut sebagai invention. Bagi masyarakat pesisir, Satria (2002) menyimpulkan bahwa umumnya proses perubahan tersebut butuh waktu lebih lama seiring dengan karakteristik masyarakatnya yang berhati-hati mengambil resiko dan mengutamakan keselamatan terlebih dahulu.

Proses perubahan teknologi perikanan juga terjadi di Teluk Tomini khususnya yang berkaitan dengan perahu nelayan dan alat tangkapnya. Perubahan tersebut berupa adaptasi dan inovasi teknologi. Adaptasi yang dimaksud dalam penelitian ini adalah upaya nelayan dalam melakukan perubahan atau penyesuaian bahan, bentuk maupun fungsi dari perahu atau alat tangkap untuk merespon kebutuhan dan perubahan yang terjadi, misalnya keterbatasan bahan alami dan tersedianya bahan sintetis. Sementara itu, inovasi yang dimaksud adalah upaya-upaya kreatif nelayan dalam menciptakan sesuatu yang baru yang berkaitan dengan perahu dan alat tangkap maupun alat bantu penangkapan untuk meningkatkan kinerja. Salam (2017) menyebutkan bahwa adaptasi teknologi sederhana dapat mendukung nelayan untuk tetap bertahan dalam eksistensinya yang diilustrasikan dengan beberapa perubahan desain pada perahu nelayan di Laut Sulawesi.

Dalam sepuluh tahun terakhir, publikasi terkait kegiatan penangkapan ikan di Teluk Tomini hanya sebatas pada penelitian tentang alat tangkap tradisional yang berkaitan dengan aspek sosial ekonomi dan aspek teknis. Penelitian yang berkaitan dengan aspek sosial ekonomi antara lain tentang kesejahteraan nelayan pancing tonda (Mareto et al. 2020); analisis keuangan pancing ulur (Mohu et al. 2019); produktivitas dan kelayakan ekonomi jaring angkat (Armain et al. 2019); kelayakan usaha jaring insang (Syarif et al. 2016); dan kesejahteraan nelayan buruh pukat cincin (Otoluwa et al. 2014). Beberapa penelitian terkait aspek teknis antara lain efektivitas bubu (Bakari et al. 2018); efektivitas alat tangkap cumi (Jula et al. 2018); efektifitas panah ikan (Nihe et al., 2017); pengaruh bentuk mata pancing terhadap hasil tangkapan pancing ulur (Panu et al. 2016); serta kajian tentang rancang bangun kapal purse seine (Fachrussyah dan Baruadi 2014). Penelitianpenelitian tersebut belum membahas aspek teknis yang terkait dengan adaptasi dan inovasi teknologi, sehingga dapat dikatakan bahwa adaptasi dan inovasi teknologi alat tangkap dan perahu nelayan yang terjadi di Teluk Tomini belum terpublikasi secara ilmiah.

Artikel ini memaparkan dan membahas hasil penelitian berupa spesimen perahu tradisional dan alat tangkap yang mewakili adaptasi atau inovasi teknologi yang dilakukan 
oleh masyarakat nelayan untuk pengembangan teknologi perikanan tangkap di Teluk Tomini khususnya di pesisir pantai selatan Provinsi Gorontalo. Jenis perahu yang diamati adalah perahu nelayan kecil di bawah 3 GT yang dioperasikan oleh 1-3 orang, yaitu perahu katinting yang menggunakan alat tangkap tagahu (Salam et al., 2016), sejenis pukat kantong untuk menangkap ikan nike, yaitu gerombolan ikan kecil yang tergolong dalam kelompok gobi bersifat amphidromous pada tahap postlarva sampai dengan juvenile (Sahami and Habibie, 2020). Komposisi spesies gerombolan ikan nike dapat dilihat pada Sahami et al 2019 dan Sahami et al 2020. Perahu katinting dipilih sebagai objek penelitian karena jenis perahu ini berteknologi sederhana yang memiliki banyak peluang pengembangan dan masih mendominasi armada perikanan tangkap di Teluk Tomini. Sementara itu, alat tangkap yang diamati adalah alat tangkap berteknologi sederhana pancing ulur cumi-cumi totabito. Alat tangkap totabito ini menjadi fenomenal dikalangan nelayan cumi-cumi di sepanjang pesisir Teluk Tomini setelah mengalami inovasi teknologi.

Penelitian ini bertujuan untuk memperoleh pengetahuan dasar tentang adaptasi dan inovasi teknologi pada perahu dan alat tangkap nelayan tradisonal di Teluk Tomini. Hasil-hasil penelitian ini diharapkan dapat menjadi rujukan untuk pengembangan perahu dan alat tangkap yang lebih baik melalui penggunaan teknologi tepat guna yang lebih maju di masa yang akan datang. Jika penelitian serupa diadakan di berbagai lokasi dengan karakteristik geografis, oseanografi dan masyarakat nelayan yang berbeda akan diperoleh konsep penerapan teknologi yang sesuai dengan karakteristik lokal di Indonesia. Selanjutnya, dapat dibuat desain kapal ikan dan alat tangkap berteknologi lebih maju yang paling sesuai dengan kebutuhan nelayan di masingmasing lokal yang dapat diperkenalkan kepada nelayan melalui program-program pemberdayaan dan pembangunan oleh pemerintah.

\section{METODE}

Penelitian ini dilaksanakan dari Juni s/d September 2020 di sepanjang pesisir pantai Provinsi Gorontalo di sisi Teluk Tomini (Gambar 1). Pembuatan perahu diamati di dua tempat, yaitu di Kelurahan Talumolo dan Kelurahan Leato Utara, Kota Gorontalo. Kedua lokasi pembuatan perahu ini secara etnis dapat mewakili teknik pembuatan perahu di sepanjang pesisir pantai Provinsi Gorontalo dengan homogenitas dominan suku Gorontalo dan penggunaan jenis-jenis perahu yang sama. Data dan informasi tentang perahu dan alat tangkap nelayan berupa jenis, fungsi, ukuran, struktur, gambar, bahan baku, perubahan bentuk, perubahan fungsi diperoleh dengan survey lapangan. Sampel secara sengaja diambil dari perahu yang sedang dibangun agar semua proses kreatif yang terjadi selama pembuatan dapat diikuti. Pengamatan alat tangkap totabito dilakukan di Desa Lamu, Kabupaten Gorontalo dimana masyarakat nelayan telah melakukan suatu inovasi pada alat tangkap tersebut yang mencerminkan adanya semangat untuk terus menerus memperbaiki kinerja alat tangkap mereka. Data fisik perahu dan alat tangkap nelayan diperoleh dengan pengamatan langsung berupa pengukuran, penggambaran, pemotretan, dan pembuatan sketsa. Wawancara mendalam dilakukan terhadap 2 orang pengrajin perahu pada 2 lokasi pembuatan perahu, 11 orang nelayan yang menggunakan perahu sejenis, dan 3 orang tokoh masyarakat di lokasi penelitian dengan menggunakan instrumen kisi-kisi wawancara. Responden dipilih secara sengaja, untuk pengrajin perahu dipilih yang sedang membuat perahu, untuk nelayan dipilih nelayan yang menggunakan jenis perahu yang telah dilakukan perubahan-perubahan dan yang menggunakan alat tangkap totabito, untuk tokoh masyarakat dipilih yang dianggap mengetahui dinamika perubahan-perubahan yang telah terjadi dalam hal penggunaan perahu dan alat tangkap.

Pengolahan data dan informasi sedapat mungkin dilakukan secara in-situ dan simultan dengan pengumpulan data untuk menjaga akurasi dan memudahkan untuk kembali memeriksa sumber asli. Data dan informasi dianalisis secara deskriptif. Kriteria yang digunakan untuk melihat adanya suatu adaptasi teknologi adalah jika terdapat upaya melakukan perubahan ataupun penyesuaian pada bahan, bentuk dan fungsi dari perahu atau alat tangkap tanpa menghilangkan karakteristik utama alat penangkapan. Sementara itu, inovasi dapat dilihat dengan adanya upaya menciptakan sesuatu disain perahu atau alat tangkap atau alat bantu penangkapan yang betul-betul baru. Data fisik perahu dan alat tangkap diolah untuk membuat gambar perahu, bentuk lambung perahu dan konstruksi alat tangkap. Data hasil wawancara disusun kembali dan disatukan berdasarkan jenis informasi. 


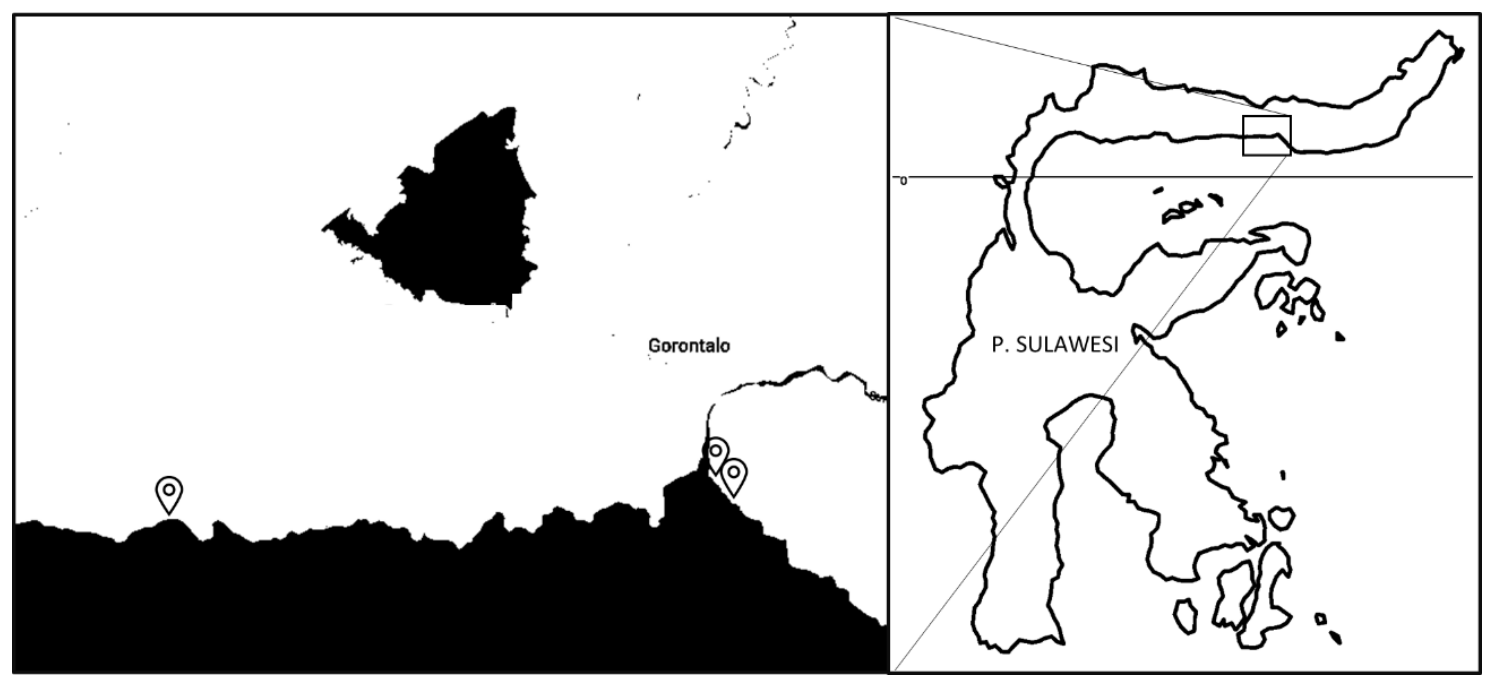

Gambar 1 Dua titik lokasi Kelurahan Talumolo dan Kelurahan Leato Utara di Kota Gorontalo dan satu titik lokasi Desa Lamu di Kabupaten Gorontalo

HASIL

\section{Perahu Nelayan Tradisional}

Pengamatan dilakukan terhadap dua buah perahu nelayan yang dibuat oleh dua orang pengrajin perahu di Kota Gorontalo. Perahu A (Gambar 2) dibuat oleh AS (42 tahun) selama tujuh minggu di dekat pemukiman warga di Kelurahan Talumolo di tepian muara Sungai Bone menghadap ke Teluk Tomini. Perahu ini disebut oleh masyarakat nelayan Teluk Tomini sebagai perahu ketinting, karena memiliki cadik pada kedua sisi perahu dan mesin luar sebagai penggerak, meskipun bentuk badannya adalah model perahu bodi (dari bahasa Inggris: body). Model perahu bodi adalah sebutan masyarakat untuk jenis perahu yang tidak memakai cadik, menggunakan mesin dalam atau mesin tempel. Perahu bodi cenderung memiliki lambung yang lebih lebar dan bagian buritan yang juga dibuat lebar pada bagian atasnya.

Badan perahu beserta semua balok dan gading-gading penguatnya terbuat dari kayu. Cadik yang berfungsi sebagai penyeimbang dan pelampung (float) pada kedua sisi perahu terbuat dari pipa PVC (polivinil klorida) berdiameter 3 inci. Dua batang cadik yang melintang badan perahu terbuat dari kayu diikat ke badan perahu dengan menggunakan tali nylon. Struktur yang menghubungkan antara cadik dan batang cadik terbuat dari bahan besi berdiameter $10 \mathrm{~mm}$ yang biasa digunakan untuk konstruksi beton yang diikatkan kepada batang dan cadik dengan tali nylon. Dimensi utama Perahu A dalam satuan meter adalah L
$=9,97 ; \mathrm{B}=1,2 ;$ dan $\mathrm{H}=0,9$ dimana $\mathrm{L}$ adalah panjang keseluruhan, $\mathrm{B}$ dan $\mathrm{H}$ adalah lebar dan tinggi yang masing-masing diukur pada bagian tengah perahu (midship).

Perahu B (Gambar 3) dibuat oleh HU (53 tahun) selama empat minggu di tepi pantai belakang rumahnya yang menghadap ke Teluk Tomini di Kelurahan Leato Utara. Bentuk dasar badan perahu ini berproporsi langsing dan tinggi, sebagaimana bentuk tradisional dari perahu ketinting. Bentuk buritan secara parsial mengadopsi bentuk buritan bodi. Pada bagian atas buritan, lebar perahu mulai dari bagian midship dibuat sama sampai pada ujung belakang, namun bentuk buritan yang meruncing pada bagian bawah masih tetap ada. Perahu ini dilengkapi dengan cadik pada kedua sisi dan digerakkan dengan mesin luar.

Badan perahu terbuat dari fiberglass dengan rangka-rangka penguat dari kayu. Pengrajin memanfaatkan cetakan perahu berbahan fiberglass yang dibuat sebelumnya untuk program bantuan pemerintah. Batang cadik terbuat dari balok kayu dan disambungkan oleh tangkai besi (diameter 10 $\mathrm{mm}$ ) dengan pelampung cadik yang terbuat dari pipa PVC berdiameter 3 inci.

Dimensi utama Perahu $B$ dalam meter adalah $\mathrm{L}=8,0 ; \mathrm{B}=0,7$; dan $\mathrm{H}=1,43$ dimana $\mathrm{L}$ adalah panjang keseluruhan, $\mathrm{B}$ dan $\mathrm{H}$ adalah lebar dan tinggi yang masing-masing diukur pada midship. Lebar perahu pada midship sampai pada buritan adalah sama. Tinggi perahu pada haluan dan buritan lebih tinggi dari pada lebar midship namun buritan lebih rendah dari pada haluan. 
Spesifikasi kedua perahu pada Tabel 1 dapat dilihat sebagai perbandingan kedua perahu yang menjadi objek amatan.

Kedua pengrajin yang membuat Perahu $A$ dan $B$ juga berprofesi sebagai nelayan dan mendedikasikan diri untuk membantu nelayan lainnya dalam hal pembuatan perahu. Pengrajin perahu tidak memiliki pendidikan formal. Sebagai masyarakat yang tinggal di pesisir pantai dengan lingkungan dan keturunan dari masyarakat nelayan tradisional kedua pengrajin belajar sendiri dengan melihat pembuatan perahu oleh pengrajin lain. Pengrajin menyesuaikan bentuk, ukuran dan bahan baku perahu dengan kebutuhan dan keinginan nelayan. Pengrajin yang mulai menggunakan fiberglass sebagai bahan pembuatan perahu telah memiliki pengalaman sebelumnya dalam pembuatan perahu untuk program bantuan pemerintah.
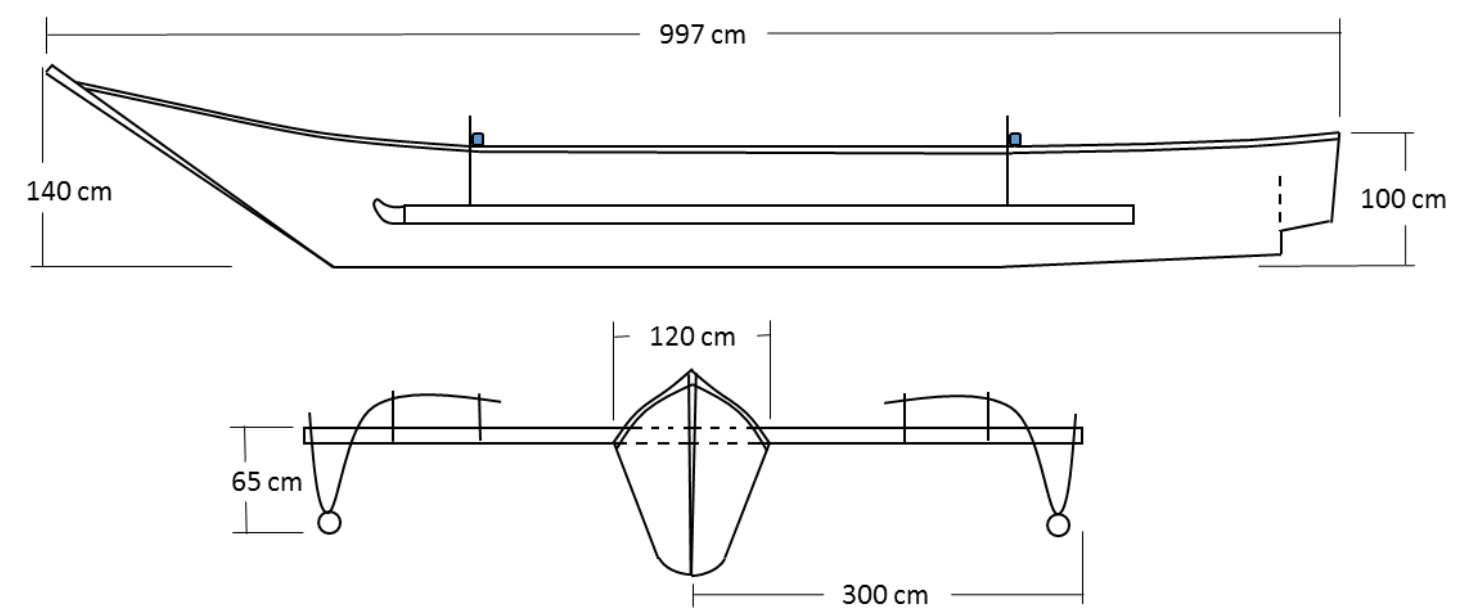

Gambar 2 Perahu A, jenis ketinting dengan lambung berjenis bodi
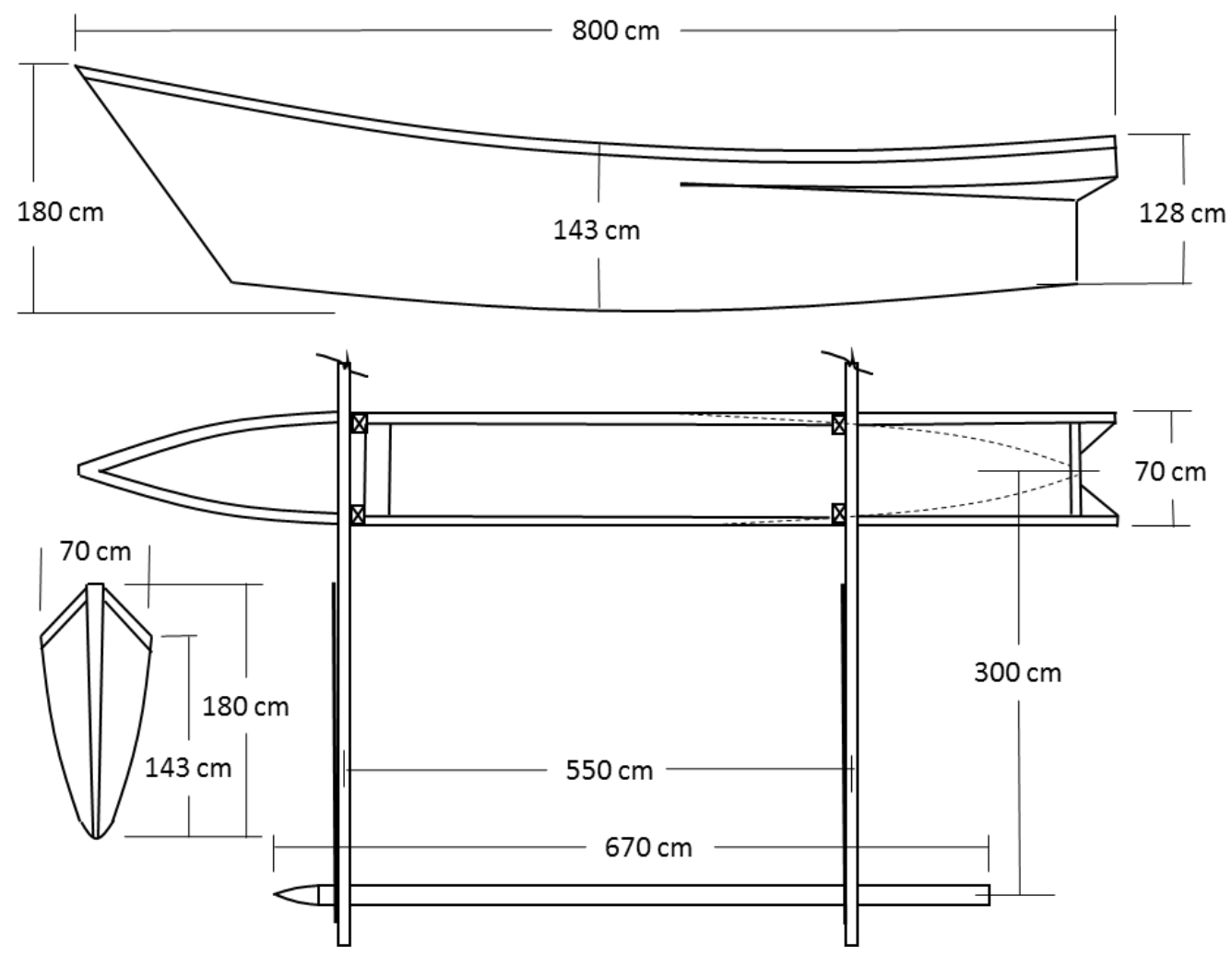

Gambar 3 Perahu B, ketinting dengan lambung tradisional berbahan fiberglass 
Tabel 1. Spesifikasi perahu objek penelitian

\begin{tabular}{lll}
\hline Spesifikasi & Perahu A & Perahu B \\
\hline $\mathrm{L}(\mathrm{m})$ & 9,97 & 8,00 \\
$\mathrm{~B}(\mathrm{~m})$ & 1,20 & 0,70 \\
$\mathrm{H}(\mathrm{m})$ & 0,90 & 1,43 \\
Jenis perahu & ketinting & ketinting \\
Badan perahu & kayu & fiberglass \\
& bodi & ketinting \\
Haluan & bodi & ketinting \\
Buritan & bodi* & bodi* \\
Cadik & PVC $^{*}$ & PVC $^{*}$ \\
Penghubung cadik & besi & besi \\
Batang cadik & kayu & kayu \\
Mesin & mesin luar & mesin luar \\
\hline
\end{tabular}

$\left.{ }^{\star}\right)$ adaptasi teknologi

\section{Alat Tangkap Totabito dengan "Lampu Suntik"}

Totabito adalah alat pancing tradisional yang digunakan oleh nelayan Desa Lamu Kabupaten Gorontalo untuk menangkap cumi-cumi (Loligo sp.) (Gambar 4). Totabito memiliki konstruksi yang hampir sama dengan pancing ulur pada umumnya, namun terdapat perbedaan khusus pada bentuk mata kail dan secara tradisional menggunakan lampu petromaks sebagai sumber penerangan eksternal pada saat pengoperasian. Totabito hasil inovasi menggunakan lampu LED (lightemitting diode) yang dimodifikasi secara khusus sebagai bagian dari alat tangkap yang ikut tercelup ke dalam air bersama mata kail. Rangkaian lampu LED dikemas di dalam tabung alat suntik bekas yang terbuat dari bahan plastik transparan, oleh karena itu lampu LED sebagai alat bantu penangkapan ini disebut juga dengan 'lampu suntik'. Bagianbagian penting dari totabito adalah penggulung, tali pancing, mata pancing totabito, kili-kili (swivel) dan lampu LED.

Penggulung terbuat dari bahan kayu berbentuk bundar dengan ukuran diameter lingkaran luar $19 \mathrm{~cm}$ dan diameter lingkaran dalam $8 \mathrm{~cm}$. Biasa juga digunakan penggulung berbentuk persegi panjang terbuat dari papan berukuran panjang kurang lebih $20 \mathrm{~cm}$. Pengulung ini dibuat sesuai dengan panjangnya tali pancing yang digunakan serta kenyamanan nelayan. Tali pancing terbuat dari bahan monofilament yang dapat diulur sampai dengan 200 meter. Tali pancing yang digunakan adalah senar nomor 15.

Kili-kili yang digunakan berbentuk barrel swivel, yang terbuat dari stainless steel. Kili-kili yang digunakan pada totabito ada dua yakni untuk menghubungkan antara senar utama dengan lampu LED dan satunya lagi untuk menghubungkan dari lampu LED ke senar yang menuju mata kail. Menurut Noija (2014), swivel biasanya dipakai pada rangkaian pancing untuk memudahkan pemasangan senar ke rangkaian mata kail sekaligus merupakan alat untuk menetralisir tali pancing saat mata kail berputar, baik akibat terkena arus air maupun ketika umpan termakan ikan dan terjadi tarik ulur.

Konstruksi lampu LED terdiri atas tabung plastik alat suntik sebagai wadah, lubang pengait pada kedua ujungnya, karet penyumbat, serta rangkaian listrik lampu LED di dalam tabung. Rangkaian lampu LED terdiri atas baterai, pegas, kabel, tombol power on/off dan lampu-lampu LED itu sendiri. Baterai yang digunakan terdiri atas tiga buah baterai kancing. Bagian mulut tabung suntik yang diisikan karet penyumbat kemudian dibalut lagi dengan lembaran karet ban sepeda untuk menjamin kekedapan terhadap air. Lampu LED yang biasa digunakan terdiri dari tiga warna yaitu hijau, biru dan kombinasi hijau, biru dan merah.

Mata pancing totabito terbuat dari lima sampai dengan enam batang kawat yang diikat menjadi satu. Ujung-ujung kawat tersebut dibengkokkan sehingga membentuk mata kail tanpa kait balik sebanyak 10 sampai dengan 12 mata kail. Hal ini sesuai dengan deskripsi Rakian (2011) bahwa mata pancing cumi berbentuk udang, ikan atau bentuk lainnya dengan mata kail yang banyak pada bagian ekor tetapi tidak mempunyai kait balik (barb). Panjang kawat mata kail totabito mencapai $19 \mathrm{~cm}$ dan panjang mata kailnya 3 $\mathrm{cm}$. Pada ujung satunya lagi terdapat lubang untuk memasukkan pengait yang mudah dipasang dan dilepas pada saat memasang umpan berupa cumi-cumi atau ikan pada 
pangkal mata kail. Penggunaan umpan dimaksudkan untuk memikat dan menarik perhatian cumi target tangkapan serta untuk merangsang penciuman cumi dan menarik penglihatan cumi target dengan cahaya lampu LED. Panjang tali yang menghubungkan kilikili dan mata kail adalah 1 meter.

Alat pancing cumi totabito dioperasikan dengan menggunakan perahu yaitu dengan cara selalu bergerak di depan gerombolan cumi sasaran. Tali pancing diulurkan secara vertikal ke bawah sampai pada kedalaman tertentu yang diduga merupakan tempat berkumpulnya cumi. Perahu yang digunakan menuju daerah penangkapan ada dua macam yaitu perahu dayung berukuran kecil $(L=3 \mathrm{~m})$ yang dioperasikan oleh satu orang nelayan dan perahu ketinting bermesin yang bisa dioperasikan oleh dua sampai tiga orang nelayan. Kedua jenis perahu terbuat dari kayu. Perahu C, berjenis ketinting (Gambar 5), adalah salah satu perahu yang digunakan oleh nelayan totabito, berukuran panjang $\mathrm{L}=$ 7 meter, lebar $\mathrm{B}=0,75$ meter dan tinggi $\mathrm{H}=$ 1,28 meter dengan menggunakan mesin berdaya $5 \mathrm{PK}$.

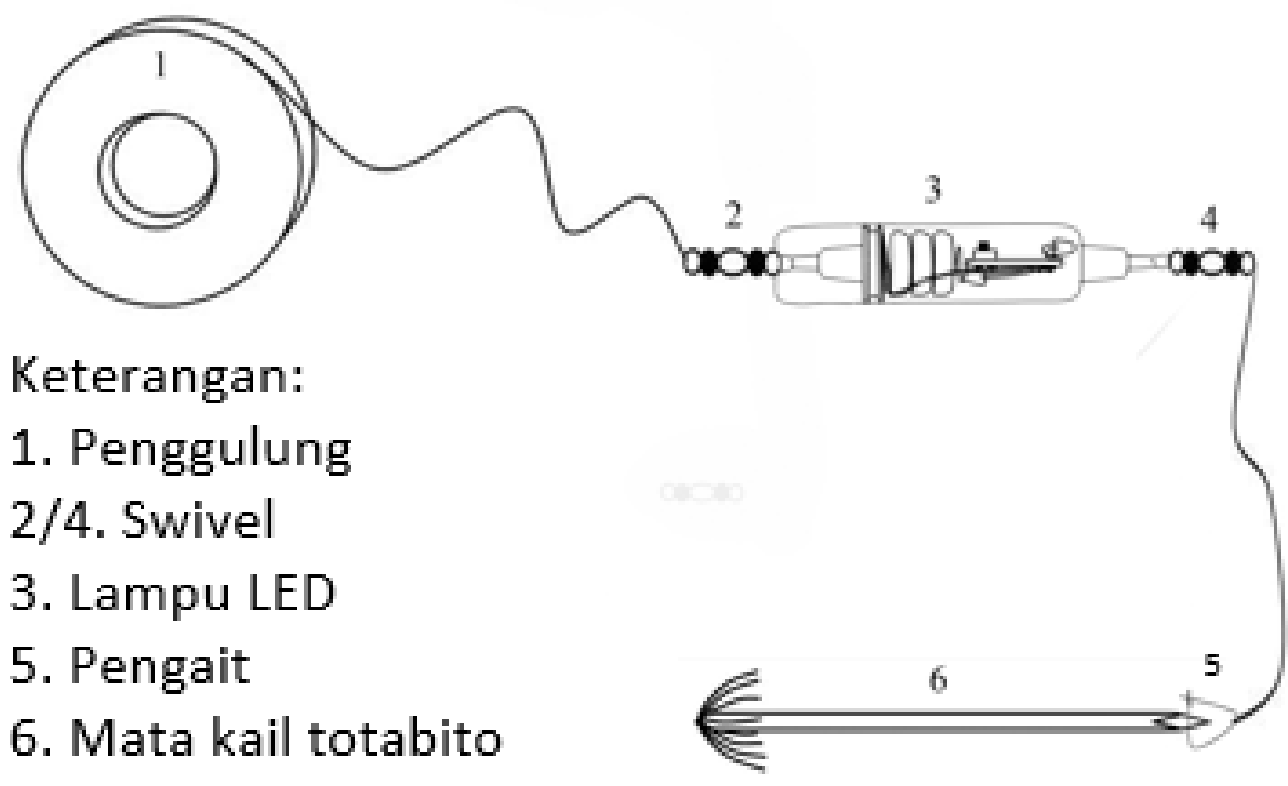

Gambar 4 Deskripsi alat tangkap totabito

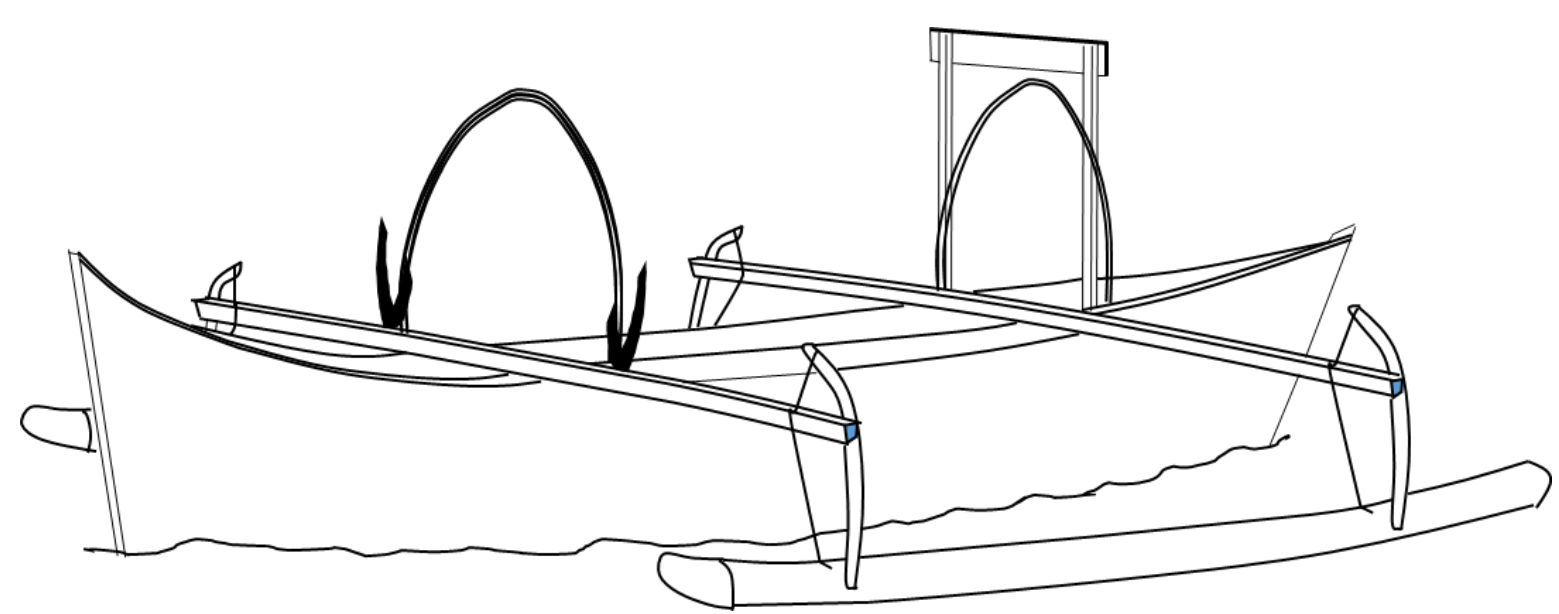

Gambar 5 Perahu C, jenis ketinting untuk pengoperasian alat tangkap cumi totabito. 


\section{PEMBAHASAN}

\section{Adaptasi Teknologi pada Perahu Nelayan Tradisional}

Perahu nelayan tradisional berbahan dasar kayu yang digerakkan dengan mesin luar di sepanjang pantai Pulau Sulawesi lazim disebut sebagai perahu ketinting. Ketinting (long-tail outboard engine) mengacu pada jenis mesin yang digunakan yaitu mesin luar yang memiliki as baling-baling yang panjang yang dicelupkan ke dalam air pada saat menjalankan perahu dan diangkat dari dalam air jika tidak digunakan. Perahu-perahu yang dibahas memiliki cadik pada kedua sisinya (double outrigger) dan menggunakan mesin luar sebagai tenaga penggerak dan disebut sebagai perahu ketinting.

Jenis lambung pada Perahu A (Gambar 2) disebut bodi. Model perahu bodi tidak dilengkapi dengan cadik, hanya badan / bodi saja. Perahu A diperlengkapi dengan cadik sehingga merupakan kombinasi atau hibrida antara perahu bercadik dan bodi dan tetap disebut sebagai perahu ketinting. Adaptasi dari bentuk lambung tradisional yang ramping dengan luas permukaan geladak yang sempit ke penggunaan lambung bertipe bodi bertujuan memperoleh geladak yang lebih lebar. Konstruksi cadik yang dipertahankan memperoleh manfaat stabilitas dan adanya platform tambahan di sisi geladak untuk mengakomodasi keperluan ruang yang lebih luas dalam penangkapan ikan tuna atau penggunaan jaring insang. Salam dan Osozawa (2008) telah menunjukkan bahwa adaptasi bentuk lambung adalah langkah bertahap bagi perahu-perahu tradisional di Nusantara, khususnya perahu BugisMakassar di Kepulauan Spermonde, dalam proses evolusinya yang antara lain menghasilkan jenis perahu phinisi yang sangat unggul pada puncak evolusi tersebut selama abad 19 sampai dengan pertengahan abad 20.

Bentuk lambung perahu tradisional di Gorontalo adalah bentuk lambung yang lancip pada haluan dan buritan. Tipikal perahu tradisional seperti pada lambung Perahu B dan perahu ketinting yang digunakan oleh nelayan totabito (Gambar 5). Proporsi lebar badan perahu kecil sehingga terlihat ramping dan tinggi dari tampak depan (seperti pada tampak depan perahu pada Gambar 3). Perahu ketinting tradisional biasanya menggunakan bahan kayu untuk lambung dan berbagai bagian perahu lainnya serta bambu untuk pelampung cadik.

Perahu A yang dikategorikan sebagai perahu ketinting karena memiliki cadik dan dirancang untuk menggunakan mesin luar mengalami adaptasi teknologi pada pemilihan bentuk badan perahu yang merupakan tipe bodi, bentuk haluannya yang sangat lancip serta bagian atas buritan yang lebar adalah tipikal bodi. Bentuk bodi juga ditandai dengan lebar badan perahu (B) yang relatif lebih lebar dan tinggi $(\mathrm{H})$ yang lebih kecil dari ukuran ketinting yang karakteristik lambungnya langsing. Adaptasi lainnya dilakukan pada pemilihan jenis bahan yang digunakan pada struktur cadik. Cadik (float) menggunakan bahan PVC dan penghubung cadik dari besi yang secara tradisional menggunakan bambu dan rotan. Alasan penggunaan bahan-bahan ini adalah ketahanan dan kemudahan dalam memperolehnya.

Perahu B (Gambar 3) juga adalah perahu ketinting. Bentuk buritan bagian atas mengadaptasi desain bodi, namun tetap mempertahankan bentuk tradisional lambung pada haluan secara keseluruhan dan pada buritan bagian bawah. Bagian atas buritan yang dibuat lebar dimaksudkan agar perahu ini dapat mengakomodasi penggunaan mesin tempel. Modifikasi bentuk buritan seperti ini sudah banyak dilakukan di Indonesia mengingat penggunaan mesin tempel juga sudah semakin luas akibat program bantuan dari pemerintah.

Perahu B lambungnya terbuat dari bahan fiberglass. Penggunaan fiberglass sebagai bahan pembuatan perahu sudah berlangsung secara luas di Indonesia kira-kira selama tiga dekade terakhir. Adaptasi teknologi perahu berbahan fiberglass di sekitar Teluk Tomini mulai terjadi pada tahun 1990an setelah mereka melihat perahuperahu yang berasal dari negara tetangga Filipina yang tertangkap melakukan illegal fishing dan ditahan di Bitung, Sulawesi Utara. Pada mulanya masih sangat sedikit yang menggunakan bahan tersebut karena masih mahal dan belum banyak dijual.

Perahu B tetap mempertahankan karakteristik lambung perahu ketinting yang langsing namun memiliki buritan bagian atas yang lebar sebagaimana buritan bodi. Adaptasi yang dilakukan adalah pemilihan bahan lambung perahu dari fiberglass serta bahan cadik dari PVC dan penghubungnya dari besi. Alasan pemilihan bahan fiberglass 
untuk lambung perahu ini berdasarkan pada pertimbangan kemudahan memperoleh bahan sintetik tersebut di toko, sementara bahan baku kayu untuk pembuatan perahu menurut pengrajin semakin sulit dan membutuhkan waktu lebih lama untuk memperolehnya. Hal ini juga didukung oleh adanya penguasaan keterampilan baru pembuatan perahu dengan bahan fiberglass.

Namun, bagi pengrajin HU (53 tahun) yang membuat perahu ini, penggunaan fiberglass sebagai bahan pembuatan perahu adalah suatu langkah baru. Jika kemudian perahu berbahan fiberglass ini menunjukkan unjuk kerja yang baik, pengrajin optimis bahwa nelayan di kampungnya akan memesan lebih banyak perahu berbahan fiberglass. Dengan demikian akan berkembang suatu tradisi baru dalam masyarakat nelayan yang sudah tidak lagi terlalu bergantung pada bahan baku kayu yang akhir-akhir ini dirasakan oleh pengrajin semakin sulit diperoleh. Sangat jelas bahwa program bantuan pemerintah telah berhasil mengenalkan suatu adaptasi baru dalam hal pemilihan bahan baku pembuatan perahu di daerah Teluk Tomini. Hal ini sejalan dengan pengamatan Akudugu et al. (2012) dan juga Kabunga et al. (2012) bahwa adaptasi teknologi dan penerimaan inovasi dapat terlihat pada proses perubahan perilaku berupa pengetahuan, sikap, dan keterampilan.

\section{Inovasi Teknologi pada Alat tangkap Totabito}

Alat pancing cumi totabito secara tradisi menggunakan alat penerang di atas permukaan air untuk menarik perhatian cumicumi. Lalu kemudian nelayan mendapati bahwa penggunaan lampu suntik meningkatkan hasil tangkapan. Penelitian Jula et al (2018), menunjukkan bahwa totabito yang menggunakan lampu suntik rata-rata dapat menangkap 242 ekor cumi per trip atau sekitar dua kali lebih banyak dari hasil tangkapan totabito tanpa lampu suntik. Kemudian, totabito dengan lampu LED berwarna biru memiliki efektivitas paling besar yaitu 41,89\% dibandingkan dengan lampu LED berwarna hijau $(29,91 \%)$ dan kombinasi warna merah, hijau dan biru $(28,21 \%)$. Totabito dengan lampu LED berwarna biru dapat menangkap cumi-cumi rata-rata 304 ekor per trip.

Lampu LED dalam bentuk lacuda (lampu celup dalam air) telah dilaporkan penggunaannya pada pengoperasian pancing ulur untuk menangkap ikan selar kuning (Selaroides leptolepis) di Pulau Morotai, Maluku Utara (Ahmad et al, 2020). Penggunaan lacuda pada pancing ulur ikan selar kuning berbeda dengan penggunaan lampu suntik pada totabito. Pada pancing ulur ikan selar kuning lacuda diturunkan kedalam air secara terpisah dengan alat tangkap, sedangkan lampu suntik melekat pada setiap alat tangkap totabito.

Penggunaan lampu suntik pada alat tangkap totabito adalah sebuah inovasi yang dilakukan oleh nelayan secara mandiri. Kenyataan bahwa alat bantu tersebut dapat meningkatkan hasil tangkapan, sebagaimana ditunjukkan pada hasil penelitian Jula et al (2018), membuat inovasi ini segera mendapat penerimaan oleh seluruh nelayan totabito di Desa Lamu. Demikian pula rangkain elektronik yang sederhana, harga terjangkau dan bahan-bahan yang mudah diperoleh, serta teknik pembuatan yang mudah adalah faktor-faktor yang diduga menjadi pendorong cepatnya penerimaan, bahkan kemungkinan akan diadopsi oleh nelayan penangkap cumi di desa-desa lain sepanjang pesisir Teluk Tomini.

\section{KESIMPULAN}

Adaptasi dan inovasi teknologi yang terjadi secara parsial pada perahu nelayan dan alat tangkap mengarah kepada pengembangan teknologi perikanan tangkap tradisional. Bentuk-bentuk adaptasi teknologi yang terjadi pada perahu nelayan di Teluk Tomini antara lain adalah penggunaan jenis lambung bodi pada perahu ketinting serta penggunaan bahan fiberglass serta pipa PVC dan besi sebagai pengganti bahan baku alami kayu, bambu dan rotan untuk badan perahu dan struktur cadik. Pada alat tangkap cumi totabito nelayan melakukan inovasi teknologi dengan membuat sendiri rangkaian lampu suntik sebagai alat bantu light fishing untuk meningkatkan hasil tangkapan.

\section{SARAN}

Sebaiknya dilakukan penelitian lanjutan untuk menemukan kombinasi berbagai adaptasi dan inovasi teknologi yang dapat dijadikan suatu rancangan dasar teknologi tepat guna pada perahu nelayan dan alat tangkap tradisional untuk menghasilkan suatu disain perahu dan alat tangkap yang lebih maju. 


\section{UCAPAN TERIMA KASIH}

Penelitian ini adalah bagian dari skema penelitian Pengembangan Dasar Keilmuan, Bidang Unggulan: Pengembangan Budaya dan Inovasi, Topik Unggulan: Inovasi Riset Fundamental. Penelitian ini dibiaya dari Dana PNBP Tahun Anggaran 2020 pada Lembaga Pengabdian dan Penelitian Universitas Negeri Gorontalo. Peneliti mengucapkan terima kasih tak terhingga kepada para pengrajin perahu dan nelayan di sepanjang pesisir pantai Teluk Tomini atas pembelajaran yang telah kami terima selama penelitian ini.

\section{DAFTAR PUSTAKA}

Agusliana MSE, Tadjuddah M, Mustafa A. Ahmad S, Ary A, Sofiati T, Piana JE. 2020. Efektifitas pencahayaan menggunakan light emitting diode (LED) pada perikanan pancing ulur untuk menangkap Selar Kuning (Selaroides leptolepis) di perairan Pulau Morotai. Jurnal IImu Kelautan Kepulauan 3 (1): 106-118.

Akudugu, M., Guo, E., Dadzie, S. 2012. Adoption of Modern Agricultural Production Technologies by Farm Households in Ghana: What Factors Influence their Decisions? Journal of Biology, Agriculture and Healthcare 2 (3).

Armain F., Abd Hafidz Olii, Alfi Sahri Baruadi. 2019. Productivity and Feasibility of Liftnet Fishery in Kwandang. Nikè: Jurnal Ilmiah Perikanan dan Kelautan 7 (1):1316. Fakultas Perikanan dan IImu Kelautan - Universitas Negeri Gorontalo.

Bakari Y, Abd Hafidz Olii, Alfi Sahri Baruadi. 2018. Efektivitas Alat Tangkap Bubu dengan Umpan Berbeda untuk Ikan Baronang | Effectiveness of bubu fish trap with different baits for baronang fish. Nikè: Jurnal Ilmiah Perikanan dan Kelautan 6 (1): 8-10. Fakultas Perikanan dan IImu Kelautan - Universitas Negeri Gorontalo.

Biro Pusat Statistik. 2019. Jumlah Rumah Tangga/Perusahaan Perikanan Tangkap Menurut Provinsi dan Jenis Penangkapan, 2000-2016. https://www.bps.go.id/statictable/2014/0 1/10/1709/jumlah-rumah-tanggaperikanan-tangkap-menurut-provinsi- dan-jenis-penangkapan-2000-2016.htm dikutip 07 Oktober 2020 [09:39am].

Fachrussyah Z.C., Alfi Sahri R. Baruadi. 2014. Kajian Rancang Bangun Purse Seiner yang Berpangkalan di PPI Tenda Kota Gorontalo. Nikè: Jurnal IImiah Perikanan dan Kelautan 2 (2): 78-80. Fakultas Perikanan dan IImu Kelautan Universitas Negeri Gorontalo.

Jula I.A., Alfi Sahri Remi Baruadi, Aziz Salam. 2018. Efektivitas Alat Tangkap Cumi Totabito di Desa Lamu | Effectiveness of squid fishing gear totabito in Lamu Village. Nikè: Jurnal Ilmiah Perikanan dan Kelautan 6 (1): 23-28. Fakultas Perikanan dan Ilmu Kelautan Universitas Negeri Gorontalo.

Kabunga NS, Dubois T, Qaim M. 2012. Yield effects of tissue culture Bananas in Kenya: Accounting for selection bias and the role of complementary inputs. Journal of Agricultural Economics 63 (2): 444 464.

Mareto, R.D., Aziz Salam, Alfi Sahri Baruadi. 2020. Welfare level of Troll Line Fishermen in Pasokan Village. Nikè: Jurnal Ilmiah Perikanan dan Kelautan 8 (1): 88-92. Fakultas Perikanan dan IImu Kelautan - Universitas Negeri Gorontalo.

Mohu, J. I. R., Aziz Salam, Alfi Sahri Baruadi. 2019. Financial Analysis on Hand Line Fisheries in Dudepo Island. Nikè: Jurnal IImiah Perikanan dan Kelautan 7 (4): 1-3. Fakultas Perikanan dan IImu Kelautan Universitas Negeri Gorontalo.

Mustapa R, Aziz Salam, Alfi Sahri Baruadi. 2017. Pengelolaan Usaha Purse Seine di Kelurahan Leato Selatan | Management of the purse seine business in Kelurahan Leato Selatan. Nikè: Jurnal Ilmiah Perikanan dan Kelautan 5 (4): 114-121. Fakultas Perikanan dan IImu Kelautan Universitas Negeri Gorontalo.

Nihe M, Aziz Salam, Alfi Sahri Baruadi. 2017. Efektivitas Alat Tangkap Panah Ikan di Desa Bajo | Effectiveness of arrow fishing gear in Bajo Village. Nikè: Jurnal Ilmiah Perikanan dan Kelautan 5 (1): 8-11. Fakultas Perikanan dan IImu Kelautan Universitas Negeri Gorontalo.

Noija, D. 2014. Mekanisasi Pancing Ulur Untuk Meningkatkan Efektivitas Dan 
Efisiensi Penangkapan Ikan Demersal di Perairan Pulau Ambon - Provinsi Maluku [Tesis]. Institut Pertanian Bogor. Bogor.

Otoluwa F.R., Aziz Salam, Alfi Sahri Baruadi. 2014. Tingkat Kesejahteraan Nelayan Buruh Pukat Cincin di Kelurahan Tenda Kota Gorontalo. Nikè: Jurnal IImiah Perikanan dan Kelautan 2 (4): 152-155. Fakultas Perikanan dan IImu Kelautan Universitas Negeri Gorontalo.

Panu I, Alfi Sahri Baruadi, Zhulmaydin Chair Fachrussyah. 2016. Pengaruh Bentuk Mata Pancing Terhadap Hasil Tangkapan Pancing Ulur | Effect of the shape of the hook on the catch of hand line fishing. Nikè: Jurnal IImiah Perikanan dan Kelautan 4 (2): 64-67. Fakultas Perikanan dan IImu Kelautan Universitas Negeri Gorontalo.

Rakian, T. 2011. Pengaruh Pancing Jigs Buatan Pabrik dan Nelayan Terhadap Hasil Tangkapan Sotong (Sepia sp.) [Skripsi]. Universitas Sam Ratulangi. Manado.

Sahami F. M., Kepel R. C., Olii A. H., Pratasik S. B. 2019. What species make up the Nike fish assemblages at the macrotidal estuary in Gorontalo Bay, Indonesia? [version 1; peer review: 2 approved with reservation]. F1000 Research 8:1654.

Sahami F. M., Kepel R. C., Olii A. H., Pratasik S. B., Lasabuda R., Wantasen A., Habibie S. A. 2020 Morphometric and genetic variations of species composers of Nike fish assemblages in Gorontalo Bay Waters, Indonesia. Biodiversitas 21 (10): 4571-4581.

Sahami F. M., Sitty A. Habibie. 2020. Exploration of adult phase of Nike fish to maintain its sustainability in Gorontalo Bay waters, Indonesia. AACL Bioflux 13 (5): 2859-2867. http://www.bioflux.com.ro/aacl

Salam A., Katsuya Osozawa. 2008. Technological Adaptation in the Transformation of Traditional Boats in the Spermonde Archipelago, South Sulawesi. Journal of Southeast Asian Studies 46 (2): 200 - 227.

Salam A., Femy M. Sahami, Citra Panigoro. 2016. Nike (Awaous melanocephalus) Fishery and Mercury Contamination in the Estuary of Bone Bolango River. Omni-Akuatika 12 (2): 130 - 136.

Salam A. 2017. Technological adaptation in traditional fisheries: way to survive. $I O P$ Conference Series: Earth and Environmental Science, Volume 139, The 2nd International Symposium on Marine and Fisheries Research 24-25 July 2017, Yogyakarta, Indonesia. Published under licence by IOP Publishing Ltd. DOI:10.1088/17551315/139/1/012038.

https://iopscience.iop.org/article/10.1088 /1755-1315/139/1/012038

Satria, Arif. 2002. Pengantar Sosiologi Masyarakat Pesisir. Pustaka Cidesindo. Jakarta.

Syarif S, Sitti Nursinar, Syamsuddin. 2016. Analisis Kelayakan Usaha Jaring Insang Dasar di Desa Pohuwato Timur | Feasibility Analysis of Bottom Gillnet in Pohuwato Timur Village. Nikè: Jurnal Ilmiah Perikanan dan Kelautan 4 (4): 120-126. Fakultas Perikanan dan IImu Kelautan - Universitas Negeri Gorontalo. 